\title{
Opening Pandora's box? Inclusive institutions and the onset of internal conflict in oil-rich countries
}

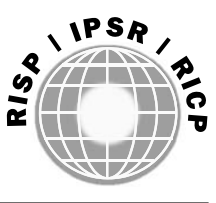

International Political Science Review 34(4) 392-410

(C) The Author(s) 2013 Reprints and permissions: sagepub.co.uk/journalsPermissions.nav DOI: $10.1177 / 0192512112467214$ ips.sagepub.com

@SAGE

\section{Tim Wegenast}

University of Konstanz, Germany

\begin{abstract}
The literature on institutional determinants of intra-state violence commonly asserts that the presence of multiple political parties reduces the conflict potential within countries. By co-opting oppositional groups into an institutionalized political arena, dissidents would prefer parliamentary means over violent rebellion in order to pursue their goals. The present article shows that this proposition does not necessarily hold true for resource-abundant states. In the presence of vast natural resources such as oil, countries exhibiting numerous non-competitive parties are actually more susceptible to internal conflict. Logit models that employ different estimation techniques and alternative operationalizations are shown to corroborate the proposed claim.
\end{abstract}

\section{Keywords}

institutions, intra-state conflict, natural resources, oil, political parties

\section{Introduction}

Commodities such as oil, gas, gold or diamonds are believed to have special properties that shape the internal political equilibrium of countries (e.g. Ross, 2012). This situation has lasting consequences for their economic development. The exploitation of such commodities produces rapid wealth, leading to overvalued national currencies, rent-seeking behaviour, greed, grievance, weak institutions and authoritarianism.

Following this reasoning, a growing body of literature has advanced our knowledge of the relationship between natural-resource abundance and conflict propensity (e.g. Collier, 2000; Collier and Hoeffler, 2004; de Soysa, 2002; Fearon, 2005). A parallel strand of the literature has focused on the institutional determinants of internal violence. Scholars have concentrated on the type of regime in place or specific political characteristics - such as the electoral system, electoral

\section{Corresponding author:}

Tim Wegenast, Department of Politics and Management, University of Konstanz, Box D86, 78457 Konstanz, Germany. Email: tim.wegenast@uni-konstanz.de 
competition, the structure of the legislation, executive power, federalism and/or secure property rights - in order to explain why some states are more conflict-ridden than others. Surprisingly, though, the question of how these different political rules affect the likelihood of conflict within natural-resource-rich countries remains largely unexplored.

This article seeks to address this shortcoming in the literature by asking how formal political institutions might affect the outbreak of internal violence in countries with abundant natural resources of their own. In particular, it analyses whether the joint presence of multiple political parties and natural resources affects the risk of civil conflict occurring. As has been pointed out by several authors already, political parties may co-opt broad segments of society into the political system, 'encapsulating' potential oppositional forces and thereby ensuring regime stability and peace (Lijphart, 1977; Linz, 1973; O’Donnell, 1973). Absorbed into an institutional framework, possible dissidents opt for legal and parliamentary means in order to articulate their interests and pursue their political goals, rather than resorting to violence.

For many autocrats, however, the concession to political parties may be a mixed blessing. While such parties may prevent unsatisfied and disaffected members of the elite or the population at large from undertaking violent opposition, they are often also associated with a loss of political control. New parties may not behave according to the interests of the autocratic government. This article argues that a context of political pluralism in which only one party has effective power is cause for trouble within a resource-rich environment.

By establishing political parties, dissidents may broaden their geographic scope of influence, enjoy greater media coverage and recruit more followers, thereby strengthening their position within the country. In giving political power away, rulers may partly lose their capacity to control these societal groups, who may take advantage of this window of opportunity to unleash violent revolt. Under these circumstances, resources such as oil may act as a kind of 'honey pot' (de Soysa, 2000: 115), providing incentives for profit-seeking groups to engage in greed-motivated and mutinous behaviour so as to gain control over the key bodies that manage resource revenue distribution. Moreover, resources may endow rebels with the financial means for predatory behaviour.

Besides acting as a honey pot and making rebellion financially feasible, resources may cause grievances (e.g. related to an unequal distribution of revenues, environmental degradation, migratory flows and/or social inequality) that provide a seemingly legitimate motive for rebellion. Political parties may appeal to these grievances, facilitating the recruitment of active followers and sympathizers within the population and mobilizing them for insurgency.

Logistic regressions confirm the article's claim that a multi-party system in which only one party holds effective political power increases the likelihood of internal violence occurring within oil-rich countries. ${ }^{1}$ The empirical results contradict the general belief that inclusive institutions always enhance peace (e.g. O’Donnell, 1973) and question the usefulness of allcountry samples when studying the institutional determinants of intra-state conflict. Rather, it seems the logic of resource-rich states is different, as governmental attempts to co-opt the opposition by establishing a multi-party system are hampered within a context of resource abundance.

The next section reviews the existing literature on the impact of natural resources and political institutions on internal violence. The article's main argument is then presented, with light shed on why inclusive institutions like multiple parties may actually instigate insurgency in resourceabundant countries. The fourth section outlines the research design employed by the statistical analysis, which is followed by the quantitative findings. The last section draws conclusions and indicates areas for future research. 


\section{Review of research on resources, institutions and internal conflict}

A substantial number of empirical studies have corroborated the notion that the extraction of natural resources is associated with a higher risk of internal conflict onset, through different causal mechanisms. ${ }^{2}$ According to many authors, primary commodities often increase the risk of civil war by providing the opportunity to finance large-scale violence, making warfare feasible (Collier and Hoeffler, 2004; Lujala, 2010). Resources may also provide a motive for taking up arms - due to resource-related grievances such as forced migration, ecological distress, environmental damage and/or the withholding of resource revenues. Costs and benefits related to resource extraction may be the driving forces of conflict (Collier and Hoeffler, 2004; de Soysa, 2002; Ross, 2003, 2012). Finally, resources may indirectly impact civil conflict onset by weakening state institutions and instigating predatory rent-seeking institutions (Fearon and Laitin, 2003; Humphreys, 2005; Thies, 2010).

However, the violence-enhancing effect of primary commodities has been increasingly questioned by a number of scholars (e.g. Brunnschweiler and Bulte, 2009). As a result, some authors have started to focus on the precise conditions under which primary commodities unleash violence (e.g. Basedau and Wegenast, 2009; Collier and Hoeffler, 2005). Contextual conditions considered by the literature include: characteristics of the available resource(s) (Snyder and Bhavnani, 2005); the market conditions under which the commodities are produced (Lujala et al., 2005); the sociodemographic environment (Sorens, 2011); the point in time at which revenues arrive (Humphreys, 2005); or the lootability of resources (Le Billon, 2008; Lujala, 2010). The likelihood of civil war occurring may be further influenced by the amount of resource revenues and by the clientelistic policies that have been devised to buy out contenders or to effectively suppress dissent (Basedau and Lay, 2009; Fjelde, 2009).

Parallel to these studies on the resource-conflict nexus, a growing amount of literature has fruitfully examined the political determinants of violence. Thus far, scholars have concentrated primarily on a possible link between regime type and civil war. A frequently heard claim is that strongly institutionalized environments (e.g. strong democracies) reduce internal violence, as they provide a forum for the peaceful settlement of conflict (e.g. Hegre et al., 2001). Furthermore, full democracies provide more public goods and protect individual civil rights, raising the costs of rebellion and reducing the support of the citizenry for insurgency. ${ }^{3}$

Consistent autocracies seem to decrease internal conflict as well (e.g. Henderson and Singer, 2000). In contrast, mixed political regimes (i.e. polities with both democratic and autocratic characteristics) are believed to spur rebellion, as they can neither ensure conflict settlement by a legitimized democratic process nor repress political challenges to state authority. In fact, many researchers find that the relationship between level of democracy (e.g. as captured by the Polity II score) and risk of civil war follows an inverted U-shape (Fearon and Laitin, 2003; Hegre et al., 2001). Carey's (2007) work challenges the parabolic relationship between level of democracy and conflict found by previous studies. While so-called 'anocracies' do not affect the risk of insurgency, the author finds that single-candidate and multi-party elections decrease the probability of violence breaking out, as compared with environments with no executive elections. Carey's message is thus clear: 'any election is better than no election' (Carey, 2007: 59). ${ }^{4}$

The idea that inclusive institutions can co-opt the potential opposition into the political system - already addressed by O'Donnell (1973) - has a long tradition of currency within Political Science. Recently, Schneider and Wiesehomeier (2008) demonstrated that rulers encouraging power-sharing institutions - such as proportional electoral systems - lower the risk of violence within diversified 
societies. Disaffected or greedy groups seem to be more easily absorbed under these conditions. Federalism is believed to co-opt regional elites into the power structure as well, significantly reducing the likelihood of violence (Saideman et al., 2002).

Inclusive institutions seem to offer a forum for mounting opposition to express its dissent, thereby reducing the readiness for rebellion. Lijphart (1977), for example, advances the possibility of social forces being appeased by the establishment of co-optation rules that encourage power-sharing. According to Gandhi and Przeworski (2006: 15), legislatures may 'absorb the political energies of groups that otherwise might attempt to overthrow the dictator'. Wright (2008) stresses that through the creation of legislation and political parties, the ruler grants the moderate opposition a forum in which they can present their demands.

Empirical studies have only recently begun to open the black box of autocratic regimes and started to concentrate on the institutional variations within autocracies. Although Huntington (1968) asserted that multiple parties have a stabilizing effect on the tenure of autocratic rulers, empirical evidence of the link between party systems and the onset of civil violence is still scant. Carey's finding that multi-party executive elections reduce the risk of insurgency, reported earlier, is limited to sub-Saharan Africa (Carey, 2007). Schneider and Wiesehomeier (2008) underscore that an intermediate number of parties increase the conflict potential in fractionalized societies. Their conclusions, however, are based exclusively on a sample of democratic countries and are restricted to highly fractionalized societies. Moreover, to the best of my knowledge, there has been no attempt to study this relationship specifically within the context of oil-abundant states. The various strands of literature assessing the impact of natural resources and political institutions on internal conflict propensity have evolved independently of each other to date.

The present article can thus be viewed as an attempt to unify the literatures on the institutional and geographic determinants of civil wars. It seeks to further our understanding of how institutional arrangements - such as the number of political parties - may shape the interaction between state and non-state actors in a context of high resource revenues. For this purpose, it will draw on institutional characteristics that are common to both autocracies and democracies.

\section{Political parties, oil and the temptation of rebellion}

According to many of the studies presented earlier, governments often rely on nominally democratic institutions in order to solicit the cooperation of outsiders and to thwart the threat of rebellion. Nevertheless, it has to be stressed that autocratic rulers are reluctant to promote more inclusive institutions that encourage power-sharing. When establishing legislatures, parliaments or political parties, such rulers always run the risk of losing control over policymaking. A policy concession - like multiple parties - only represents an effective mechanism by which the risk of rebellion can be countered if it can be tightly controlled by the autocrat.

In general, resource-rich authoritarian countries are believed to avoid the establishment of inclusive institutions, as possible discontent is dissipated through the wider distribution of spoils. As outlined by Gandhi and Przeworski (2006: 2-3), the rentier state (Mahdavy, 1970) needs little cooperative support from outsiders as it can rely on the sharing of rents from natural resources to counter the threat from dissidents (see also Wright, 2008: 322-323). Oil-rich countries are often perceived as distributive states, where governments are mainly concerned with the internal distribution of rents (Karl, 1997). Consequently, these countries make fewer institutional concessions. In a similar vein, Fjelde (2009) demonstrates that oil-abundant governments can rely on political corruption as a way to buy consent, and thereby co-opt key segments of society. 
Table I. Number of parties across oil-abundant and oil-scarce states.

\begin{tabular}{lccc}
\hline $\begin{array}{l}\text { Number of political parties } \\
\text { within the legislature }\end{array}$ & Oil-abundant & Oil-scarce & Total \\
\hline 0 & 264 & 726 & 990 \\
& $61.97 \%$ & $21.77 \%$ & $26.32 \%$ \\
1 & 111 & 1493 & 1604 \\
& $26.06 \%$ & $44.77 \%$ & $42.65 \%$ \\
or more & 51 & 1116 & 1167 \\
Total & $11.97 \%$ & $33.46 \%$ & $31.03 \%$ \\
& 426 & 3335 & 3761 \\
& $100 \%$ & $100 \%$ & $100 \%$ \\
\hline
\end{tabular}

Table 1 plots dictatorships according to their resource wealth and the number of political parties operating in them. Following the classification proposed by Przeworski et al. (2000), a country is considered a dictatorship when at least one of the following explicit objective criteria holds true: the chief executive and the legislature are not competitively elected; there is not more than one party competing for office; or there has been no alteration in power. Regarding resource wealth, countries are classified as oil abundant if their daily per capita oil production exceeds the 90th percentile of all the countries in the sample..$^{5}$ The variable measuring the number of political parties within legislatures comes from Gandhi and Przeworski (2006). It takes the value of 0 when there are no parties or when there are multiple parties but no legislature, 1 where there is one party, and 2 in cases where there is more than one autonomous party in the legislature. ${ }^{6}$

As evidenced by Table 1, around $62 \%$ of the autocratic, oil-abundant states have no parties or legislatures. Nevertheless, almost $12 \%$ of them do exhibit more than one autonomous party. ${ }^{7}$ Regardless of the reasons for the establishment of multiple parties, this article assesses the consequences of maintaining these inclusive institutions for the internal violence propensity of resourcerich countries. ${ }^{8}$

Political parties help opposition groups to organize themselves, possibly granting them a degree of influence over policymaking. Under the mantle of a political party, dissidents may broaden their geographic scope, enjoy greater media coverage, get access to public funds - as well as to key bodies governing the distribution of resource revenues - and recruit followers more easily. Fortified by formal institutions, they may be tempted to resort to armed rebellion when natural resources provide a strong motive and the necessary financial means. Under these conditions, the costs of dissent are reduced since the opposition is better organized, the expected value from victory (viz. control over resource revenues) is high and there are now means to finance the undertaking. Enjoying enhanced articulation capacity and the support of broader groups within society, oil may push the temptation to depose incumbent rulers or to seek secession. In a nutshell, it can be said that when there are oil revenues involved, the stakes are higher for political competition, encouraging rival parties to use violence in order to gain exclusive control over state revenues.

The struggle over the control of oil or gas production is believed to be the driving force behind various episodes of internal violence, such as the civil wars in Angola, Colombia, the Democratic Republic of Congo (DRC), Indonesia and Sudan (Ross, 2004). Collier and Hoeffler (2006) show that resources can foster conflict by inspiring economically motivated secession attempts. Describing the cases of Nigeria and the DRC, the authors demonstrate that the discovery of oil generated strong financial incentives to create new regions. 
In the majority of cases, holding a political position is an important precondition for gaining official control over the acquisition and distribution of resource rents. The establishment of political parties may thus facilitate access to key bodies that control resource revenues. This is evident in countries such as Colombia, Nigeria and the Republic of the Congo, among others. According to Obi (2001: 173), for example, the Nigerian state is 'a site of constant struggles for access to power and resources, in which those in power defend themselves at any cost, and those outside seek entry at any cost and through any means'. Lewis (1994) goes as far as to characterize Nigerian politics simply as a process of competition for access to oil revenue. After the Marxist-Leninist single-party state was replaced by a semi-democratic regime in the Republic of the Congo, the two political parties contending for power - of presidential candidates Pascal Lissouba and Denis Sassou-Nguesso - fought fiercely over the control of oil.

In addition to attempts at controlling resource revenues being motivated by greed, violent rebellion seeking to overthrow governments may also be driven by internal political and resourcerelated grievances. Disaffected at not having effective leverage over the decision-making process, and distressed over political repression against them, the opposition may resort to non-parliamentary means in order to achieve political control. Realizing that coming into power by a normal legislative process is impossible, dissidents are likely to take up arms instead. Political repression - such as the promotion of fraudulent elections, the imprisonment of the opposition, the banning of parties, or assassinations - may provide seemingly legitimate motives for remedying grievances and ending tyranny. ${ }^{9}$

Furthermore, grievances caused by natural-resource extraction - such as the unfair distribution of revenues, environmental distress, the loss of land rights and/or forced migration (Ross, 2004: 41) - may be aired by oppositional parties, helping to mobilize disaffected segments of society for insurgency. Regime opponents - organized around political parties and sworn to putting an end to a seemingly unjust situation by any available means - may enjoy considerable support among the local population. In this way, real or imagined grievances can legitimize violence.

Aside from supplying a motive, natural resources may also create the opportunity for rebellion by providing the necessary financial means. Le Billon (2001), for example, stresses the opportunity structures for armed insurgents resulting from the lootability of resources. By using the threat of kidnapping or of blowing up pipelines, rebels impose so-called 'war taxes' on those who extract and sell resources. In addition, internal violence can be funded by selling the rights to extract fuels in the future. ${ }^{10}$ Hence, the co-option of oppositional groups through the establishment of political parties is a risky undertaking when mineral resources are present. Strengthened by parties, opponents may succumb to the temptation of armed rebellion more easily.

At this point, it is important to note that resource production may also have peace-buying effects, and states enjoying very high oil revenues may be able to avoid the outbreak of internal violence. Large rents allow governments to build up effective internal security apparatuses (Basedau and Lay, 2009) or to buy political consent through patronage networks, thus discouraging rebellion. This counter-insurgency capacity may offset the proposed consequences of the combination of a non-competitive multi-party system ${ }^{11}$ and oil endowment. However, governments must earn high per capita oil revenues in order to maintain domestic stability and avoid internal conflicts. As evident from the historical cases outlined later, even rentier states - such as Iraq - that have exhibited large oil rents as well as multiple political parties for a number of years still face considerable conflict potential.

Empirical cases that link internal violence to the extraction of natural resources within a political environment that is characterized by an uncompetitive multi-party system are numerous. In Colombia, for example, the emergence of the Unión Patriótica (UP) - which served as the political 
branch of the Fuerzas Armadas Revolucionarias de Colombia (FARC) - was soon perceived as a threat to the traditional political powers within the country's uncompetitive electoral system ${ }^{12}$ and contributed to an increase in intra-state violence. The political party served FARC's recruitment purposes and was an effective PR tool, spreading the guerrillas' propaganda. Moreover, the party expanded the territorial influence and social reach of the rebels.

The elections of 1986 and 1988 are widely regarded as key events, as the UP tried to gain control over the main bodies that distributed resource revenues - especially within the oil-rich provinces of Arauca and Casanare (Pearce, 2004). The prospect of amassing oil royalties caused the existing parties to be 'at the loggerheads for political control' in the Sarare region (Pearce, 2004: 20 ). Besides granting them a motive, oil enabled the FARC to finance armed insurgency. By threatening to blow up pipelines and kidnapping contract workers, the Colombian guerrillas collected protection money from oil extractors, thus filling the movement's coffers and allowing it to expand. ${ }^{13}$

The UP's electoral gains in the 1986 parliamentary elections constituted a threat to the established forces within the country. Paramilitary groups - contracted mainly by large landowners with the open support of Colombia's armed forces - started a systematic terror campaign against UP officials. The party was almost completely annihilated between the late 1980s and early 1990s. More than 3500 party members were either murdered or disappeared, including UP presidential candidates such as Jaime Pardo Leal. The political terror suffered by the UP and its members provided strong justification for the FARC's armed cause. The organization and its sympathizers often used the destruction of the UP as the casus belli for the violence employed against the Colombian state (Shifter, 1999: 15).

Other cases where internal violence can be partly connected to a scenario of multiple parties and oil wealth are Nigeria and the Republic of the Congo. The adoption of a multi-party system led to the explosion of internal violence in Nigeria. The transition process opened up a range of political opportunities for specific ethno-religious groups. Political control over oil revenues was a major cause behind the internal conflicts in Nigeria, as pinpointed by tensions around the federal government's Poverty Alleviation Programme in the Niger Delta (and the resulting uprisings). It can be said that Nigerian politics has been largely characterized by party leaders' repeated attempts to take control of oil wealth.

The Republic of the Congo is another pertinent example of the possible perils of opening up the political system in resource-abundant countries. After the fall of Sassou-Nguesso's dictatorship and the staging of multi-party elections in August 1992, the country was afflicted by severe clashes between government forces, militias and rebel groups who supported the three major candidates: Sassou-Nguesso, Pascal Lissouba and Bernard Kolelas. The enduring militia fighting killed many thousands of people and culminated in the 1997 civil war. Ongoing attempts to gain control over the country's oil production are often seen as being a major factor in the internal violence. According to Englebert and Ron (2004: 62), their local informants uniformly believed that 'greed for petroleum rents in a new and uncertain political context was a major motivation for the war, as political leaders, drawn chiefly from Congo's governing class, struggled for control over the country's oil wealth'. ${ }^{14}$

Oil-rich states in the Middle East have also experienced internal violence partly due to political struggles over petroleum. The campaign for more autonomy by the main Kurdish parties in Iraq has resulted in a history of heavy fighting since the early 1960s. The Kurdistan Democratic Party (KDP) first demanded control over the oil-rich fields of Kirkuk - on the fringes of Iraqi Kurdistan - in 1963, provoking violent repression by troops from the Ba'ath Party. Martial law ensued, resulting in many killings and Kurdish delegates being arrested throughout Iraq. After a short peace 
agreement between the leader of the KDP, Mullah Mustafa, and the Ba'ath regime in 1970, fighting resumed in 1973 after the nationalization of oil facilities by the government and, with it, the arousal of Kurdish fears of losing exploration rights. In 1988, the resistance movement was finally defeated by government troops. The Iraqi army systematically destroyed all Kurdish villages in the north of the country that supported the rebels, and settled the oil-rich region of Kirkuk with Arab families (Wimmer, 2003). During the mid-1990s, the struggle for control of oil revenues was central to the conflict between the KDP and the Patriotic Union of Kurdistan (PUK), bringing about civil war in northern Iraq.

The next section takes a broader view, by expanding the discussion along historical lines and across a number of countries. The intention here is to examine the statistical evidence for whether or not the existence of political parties can explain the risks of insurgency in the presence of natural resources. A macro-comparative analysis addresses the question of whether multiple parties act as a co-opting instrument that reduces the propensity for civil violence or whether they, rather, accentuate perceived grievances and greedy behaviour, and thereby increase the propensity for internal conflict.

\section{Empirical analysis}

To analyse the impact of political parties on internal conflict in resource-rich countries, the study makes use of the Database of Political Institutions (DPI 2006) (Beck et al., 2001). This data set covers 177 countries from 1975 to 2006 and, among many other variables, presents a legislative index of electoral competitiveness (liec). The index has a value of: 1 if there is no legislature; 2 if there is an unelected legislature; 3 if there is an elected legislature but only one candidate; 4 if there is one party and multiple candidates; 5 if multiple parties are legal but only one party won seats; 6 if a number of parties won seats but the largest party received more than $75 \%$ of them; and 7 if the largest party achieved less than $75 \%$ of the seats. ${ }^{15}$ This form of measurement will allow an estimation of the effects of multiple parties on conflict propensity in resource-abundant autocracies and democracies. ${ }^{16}$ The index has been transformed into dummies reflecting the respective categories (e.g. liec 4 equals 1 if the political system envisages only one party but allows multiple candidates).

To measure the onset of internal violence, the UCDP/PRIO Armed Conflict Dataset (version 4/2007) was employed (Gleditsch et al., 2002). Intra-state conflict is operationalized by an indicator (violonset) that has a value of 1 if there is an onset of conflict with more than 25 annual battlerelated deaths (or it has been at least two years since the last observation of the same conflict), ${ }^{17}$ and 0 if no internal conflict started in the year under consideration. Following the suggestion made by Hegre and Sambanis (2006: 523), ongoing conflict years are coded as 0s instead of dropping them from the sample, as multiple conflicts happening in the same country are not uncommon. Fearon (2005: 488-489) argues that omitting periods of ongoing war (by treating them as missing cases) 'artificially increases the mean of the dependent variable (onset) for countries that had a war, and especially for countries with multiple onsets'.

By choosing a lower threshold for the onset of violence (i.e. not the ' 1000 battle-related deaths in at least one conflict year' marker that is often employed by the conflict literature), the dependent variable is not limited to civil wars, and conflict outbreaks are maximized. ${ }^{18}$ Also, in-depth case studies argue that rather than increasing the probability of civil war onset by providing the financial means necessary for it, resources affect the duration of civil wars (e.g. Ross, 2004). Employing a lower violence threshold allows a single country to experience a series of smaller-scale conflicts within a shorter period of time. The assumption that oil plays a role in financing these smaller, possibly interrelated, conflicts then seems more plausible. 
In order to choose the control variables to be included in the model, the results from Hegre and Sambanis (2006) were considered. These authors performed specification tests to check the robustness of 88 variables frequently used by the literature to explain civil war. Their sensitivity analysis suggests that several determinants of the onset of civil war are robust: population size; countries' income level; economic growth; recent political instability; inconsistent democratic institutions; rough terrain; and war-prone and undemocratic neighbours. All of these independent variables, taken from Hegre and Sambanis's (2006) replication data set, were included in the model. ${ }^{19}$ Ethnic fractionalization, polarization or dominance measures were ignored, as they showed no significant and robust association with the onset of civil war (as measured by UCDP/PRIO). ${ }^{20}$

All independent variables except for the regional dummy representing the Middle East and North Africa (mena) were lagged by one year in order to counter possible reverse causality. The possibility that the number of political parties is endogenous to civil conflict has to be particularly accounted for. As proposed by Gandhi and Przeworski (2006, 2007), the threat of rebellion can be reduced by making policy compromises in the form of conceding to the creation of political pluralism. Thus, the establishment of opposition parties could be a consequence of internal instability. By lagging liec, the possibility that multiple parties are a mere reflection of the threat of rebellion is hence reduced. ${ }^{21}$ Furthermore, when liec is taken as the dependent variable and internal violonset is moved to the right-hand side of the estimation equation, no statistically significant results for violonset can be reported.

The risk of internal conflict onset is estimated using logit models for the period 1975-1999. ${ }^{22}$ To minimize problems of temporal dependence on a history of conflict, a variable reflecting the duration of time since the last event/onset (peace) was included in all models, following the recommendation made by Beck et al. (1998). The necessity of employing cubic splines (also suggested by Beck et al., 1998) was rejected by likelihood-ratio tests. Additionally, 'rare-event logit models', as suggested by King and Zeng (2001), were equally estimated. These authors demonstrate that when binary dependent variables measure the occurrence of 'rare events', standard logit or probit estimations may produce biased coefficients.

\section{Empirical findings}

The empirical tests examine whether the number of political parties and oil wealth jointly affect the countries' conflict potential. To this end, calculating interaction terms would be the standard statistical procedure. However, as the majority of states are non-oil producers, an interaction variable between oil and legislative electoral competitiveness proved to be highly correlated with its constituting single terms. Thus, the introduction of an interaction would almost invariably lead to multicollinearity, producing inflated standard errors and biasing single parameter estimates. ${ }^{23}$ In order to avoid this problem, a subsample strategy dividing the states into oil-abundant and oilscarce - according to two different thresholds - was applied. As already mentioned, all-country samples may mask important differences in the institutional forces driving civil wars.

Tables 2 and 3 underline the assertion that one has to consider resource-abundant states separately when analysing the impact of institutional features - such as the number of political parties - on a society's propensity for internal conflict. The statistical significance and size of the liec4-liec7 coefficients vary considerably across the presented subsamples. ${ }^{24}$ Model 1 in Table 2 contains all countries (irrespective of their resource endowment). As is evident, a multi-party system in which the largest party obtained more than $75 \%$ of all congressional seats (liec 6 ) is significantly related to the dependent variable, increasing the likelihood of internal violence. However, when only 
Table 2. Dependent variable: internal conflict onset (violonset).

\begin{tabular}{|c|c|c|c|}
\hline & $\begin{array}{l}\text { Model I (all } \\
\text { countries) }\end{array}$ & $\begin{array}{l}\text { Model } 2 \text { (Oil-scarce, } \\
\text { below 75th percentile) }\end{array}$ & $\begin{array}{l}\text { Model } 3 \text { (Oil-rich, } \\
\text { above } 75 \text { th percentile) }\end{array}$ \\
\hline peace & $-0.012(0.009)$ & $-0.003(0.012)$ & $0.001(0.018)$ \\
\hline Natwar $_{(t-1)}$ & $0.184(0.208)$ & $0.041(0.258)$ & $0.236(0.383)$ \\
\hline population $(\log )_{(\mathrm{t}-1)}$ & $0.330(0.058)^{* * * * * *}$ & $0.334(0.067)^{* *+* k}$ & $0.263(0.156)^{*}$ \\
\hline $\operatorname{gdppc}(\log )_{(\mathrm{t}-1)}$ & $-0.463(0.139)^{* * * *}$ & 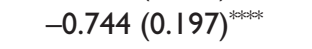 & $-0.598(0.247)^{* k}$ \\
\hline partfree $_{(t-l)}$ & $-0.022(0.244)$ & $0.235(0.292)$ & $-0.504(0.488)$ \\
\hline regchange $_{(t-1)}$ & $0.266(0.301)$ & $0.277(0.352)$ & $0.193(0.595)$ \\
\hline gdpgrowth $_{(\mathrm{t}-1)}$ & $-2.015(1.902)$ & $0.137(2.004)$ & $-5.913(2.822)^{* * k}$ \\
\hline dem_region $(\mathrm{t}-1)$ & $0.012(0.023)$ & $0.018(0.029)$ & $0.005(0.042)$ \\
\hline terrain $_{(\mathrm{t}-\mathrm{l})}$ & $0.098(0.073)$ & $0.076(0.086)$ & $0.256(0.205)$ \\
\hline mena & $0.739(0.292)^{* *}$ & $0.461(0.493)$ & $0.167(0.480)$ \\
\hline $\operatorname{liec} 4_{(\mathrm{t}-l)}$ & $-0.016(0.373)$ & $-0.189(0.458)$ & $-0.013(0.640)$ \\
\hline $\operatorname{liec} 5_{(t-1)}$ & $0.686(0.428)$ & $-0.528(1.036)$ & $\mathrm{I} .274(0.697)^{*}$ \\
\hline $\operatorname{liec} 6_{(t-1)}$ & $0.81 \mathrm{I}(0.306)^{* * * *}$ & $0.661(0.417)$ & $1.272(0.587)^{* k}$ \\
\hline $\operatorname{liec} 7_{(\mathrm{t}-1)}$ & $-0.062(0.262)$ & $0.279(0.314)$ & $-0.923(0.55 \mathrm{I})^{*}$ \\
\hline constant & $-8.825(0.939)^{* * * * *}$ & $-9.042(1.075)^{* * * * * *}$ & $-7.47 \mid(2.794)^{\text {od* }}$ \\
\hline $\mathrm{N}$ & 3925 & 2829 & 1095 \\
\hline Wald chi & 117.35 & 76.31 & 48.01 \\
\hline Prob $>\mathrm{chi}^{2}$ & 0.0000 & 0.0000 & 0.0000 \\
\hline $\begin{array}{l}\text { Pseudo R2 } \\
\text { McKelvey \& Zavoina's R2 }\end{array}$ & $\begin{array}{l}0.0892 \\
0.198\end{array}$ & $\begin{array}{l}0.0855 \\
0.193\end{array}$ & $\begin{array}{l}0.1485 \\
0.149\end{array}$ \\
\hline
\end{tabular}

Notes: Logit estimation using robust standard errors (shown in parentheses).

${ }^{*} \mathrm{p}<10 \%$; ** $\mathrm{p}<5 \%$; *** $\mathrm{p}<1 \%$; **** $\mathrm{p}<0.1 \%$.

oil-scarce states are taken into account in Model 2, the coefficient for liec6 drops in magnitude and becomes non-significant. ${ }^{25}$

In contrast, the presence of non-competitive, multi-party systems in oil-abundant countries (Model 3) seems to spur conflict potential considerably. Expressed in odds ratios, the likelihood of conflict breaking out in oil-rich states is more than three times higher when there are several political parties and one of them holds more than $75 \%$ of all the congressional seats. The same applies to situations in which countries exhibit a multi-party system in which only one party holds congressional seats (liec5 in Model 3). In contrast, a competitive multi-party system is negatively associated with internal violence in oil-abundant countries (liec7 in Model 3).

These findings suggest that rather than appeasing the opposition by co-optation, inclusive institutions - such as multiple political parties - may foment rebellious behaviour in resourceabundant states. This assertion is corroborated when the concept of resource-abundance is used in more restrictive terms (per capita daily oil production above the 90th percentile). Model 3 of Table 3, for example, indicates that the likelihood of conflict is approximately seven times higher when there are multiple parties but only one party won seats $(l i e c 5=1)$ in the oil-abundant subsample (compared with the complete lack of political parties). Thus, the coefficient's magnitude increases substantially when the definition of oil richness is narrowed. The same applies to liec6. Note that the coefficient of liec6 is also statistically significant in the oil-poor subsample (Model 2). This is partly due to the more restrictive choice of the oil abundance threshold. ${ }^{26}$ The coefficient's magnitude in Model 2, however, is considerably lower than in the oil-rich subsample. 
Table 3. Dependent variable: internal conflict onset (violonset).

\begin{tabular}{|c|c|c|c|}
\hline & Model I (all countries) & $\begin{array}{l}\text { Model } 2 \text { (oil-scarce, } \\
\text { below } 90 \text { th percentile) }\end{array}$ & $\begin{array}{l}\text { Model } 3 \text { (oil-rich, } \\
\text { above } 90 \text { th percentile) }\end{array}$ \\
\hline peace & $-0.012(0.009)$ & $-0.007(0.010)$ & $0.028(0.023)$ \\
\hline natwar $_{(\mathrm{t}-1)}$ & $0.184(0.208)$ & $0.065(0.228)$ & $0.685(0.726)$ \\
\hline population $(\log )_{(t-1)}$ & $0.330(0.058)^{* *+* k}$ & $0.336(0.060)^{* *+* *}$ & $0.613(0.365)^{*}$ \\
\hline $\operatorname{gdppc}(\log )_{(\mathrm{t}-1)}$ & $-0.463(0.139)^{* * * k}$ & $-0.698(0.170)^{* * * *}$ & $-1.279(0.492)^{\text {tovk }}$ \\
\hline partfree $_{(t-I)}$ & $-0.022(0.244)$ & $0.280(0.261)$ & $-1.426(0.861)^{*}$ \\
\hline regchange $_{(\mathrm{t}-\mathrm{l})}$ & $0.266(0.301)$ & $0.152(0.339)$ & $-0.554(0.822)$ \\
\hline gdpgrowth $_{(\mathrm{t}-\mathrm{l})}$ & $-2.015(1.902)$ & $-0.052(1.855)$ & $-8.769(3.464)^{* *}$ \\
\hline dem_region $(t-1)$ & $0.012(0.023)$ & $0.022(0.025)$ & $0.018(0.096)$ \\
\hline terrain $_{(\mathrm{t}-1)}$ & $0.098(0.073)$ & $0.109(0.078)$ & $-0.353(0.464)$ \\
\hline mena & $0.739(0.292)^{* *}$ & $0.361(0.395)$ & $0.799(1.064)$ \\
\hline $\operatorname{liec} 4_{(t-1)}$ & $-0.016(0.373)$ & $-0.171(0.423)$ & $-1.163(0.846)$ \\
\hline $\operatorname{liec} 5_{(t-1)}$ & $0.686(0.428)$ & $-0.84 I(1.025)$ & $1.975(0.762)^{* *}$ \\
\hline $\operatorname{liec6}_{(t-1)}$ & $0.811(0.306)^{* *+k}$ & $0.828(0.334)^{* *}$ & $2.549(1.325)^{* *}$ \\
\hline $\operatorname{liec} 7_{(\mathrm{t}-1)}$ & $-0.062(0.262)$ & $-0.055(0.293)$ & $0.159(0.598)$ \\
\hline constant & $-8.825(0.939)^{* * \alpha * k}$ & $-8.999(0.983)^{* * * * *}$ & $-11.262(5.274)^{* *}$ \\
\hline $\mathrm{N}$ & 3925 & 3469 & 455 \\
\hline Wald chi ${ }^{2}$ & 117.35 & 103.11 & 43.03 \\
\hline Prob $>$ chi $^{2}$ & 0.0000 & 0.0000 & 0.0001 \\
\hline $\begin{array}{l}\text { Pseudo } R^{2} \\
\text { McKelvey \& Zavoina's R2 }\end{array}$ & $\begin{array}{l}0.0892 \\
0.198\end{array}$ & $\begin{array}{l}0.0916 \\
0.207\end{array}$ & $\begin{array}{l}0.2562 \\
0.458\end{array}$ \\
\hline
\end{tabular}

Notes: Logit estimation using robust standard errors (shown in parentheses).

$*_{\mathrm{p}}<10 \% ; * * \mathrm{p}<5 \%$; *** $\mathrm{p}<1 \%$; **** $\mathrm{p}<0.1 \%$.

As evidenced by Model 1 in both tables, the independent variables show the expected signs. Highly populated states (population) - proxied by the log of the total population - as well as countries located in the Middle East and North Africa (mena) experience a higher likelihood of conflict, while more economically developed countries (measured by the log of per capita GDP $(g d p p c))$ tend to be spared from internal violence. The other independent variables remain nonsignificant. All the models were also estimated using 'rare-event logit' methods, and the results were nearly identical. ${ }^{27}$ Also, the findings obtained proved to be robust to the inclusion or exclusion of different sets of independent variables. ${ }^{28}$ In particular, all models were re-estimated including other institutional indicators, such as regime type, level of democracy (as measured by Freedom House or Polity II) or a dummy variable for presidential states, in order to address possible omitted-variable bias. Results did not change considerably. Likelihood Ratio Tests of the reported specification against several different nested models revealed that the applied full model has a proper specification. In addition, a stepwise inclusion of all independent variables indicated that the reported findings are unlikely to be driven by multicollinearity.

In addition to the robustness checks, all of the models were re-estimated by employing alternative resource endowment concepts. As already outlined, differentiating between mineral abundance and mineral dependence provides an important theoretical underpinning. When the criterion of resource dependence is applied to define the subsamples, the previously reported results remain almost identical (see Table A1 in the Appendix). ${ }^{29}$ Thus, the conflict-enhancing effect of an 
uncompetitive multi-party system does not seem to be restricted to the concept of oil abundance. Furthermore, when the absolute annual production of oil is considered (rather than the per capita figure), the findings remain identical: countries exhibiting a high oil production (above the 75 th and 90th percentiles) as well as a multi-party, non-competitive electoral system (liec5 and liec6) are more prone to experiencing internal violence. ${ }^{30}$

The reported statistical associations are in line with the proposed hypotheses. As is evident, the scenario of multiple political parties in which only one party has effective political representation in parliament (liec5 and liec6) particularly increases the conflict likelihood within resource-rich states. In such a scenario, political repression is particularly likely to occur and the lack of effective political leverage experienced by the opposition intensifies internal grievances. Disaffected by their political powerlessness, insurgents may profit from oil as a means of financing rebellion. Furthermore, the prospect of controlling oil revenues may act as a honey pot, thus encouraging the opposition to take up arms.

\section{Conclusion}

According to Huntington (1968), the presence of multiple parties ensures internal stability and prolongs the governance of authoritarian rulers. As inclusive institutions, parties are believed to co-opt the opposition into the political system, encouraging possible dissidents to pursue their goals through non-violent means and to obey the 'rules of the game'. In this sense, legislatures and parties offer a forum through which the oppositional groups can express their dissent.

While this may apply for most states, it does not seem to hold true for resource-rich countries. The present analysis indicated that, compared with oil-rich countries that have no elections or only one political party, oil-abundant economies exhibiting an electoral system with multiple parties in which only one of them has any effective political power display a higher conflict potential. By testing the effect of multiple parties on internal violence across subsamples of oil-abundant and oil-scarce countries, the empirical analysis corroborated this proposition. Thus, the premise that 'any election is better than no election' (Carey, 2007: 59) does not actually seem to be correct in the case of oil-abundant (and oil-dependent) states.

Different interconnected explanations for the violence-enhancing effect of multiple political parties within an oil-abundant environment have been proposed. By helping the opposition to overcome its collective action problem and to organize itself, parties may strengthen regime dissent. Tempted by the prospect of high future rewards (from controlling the revenues gained from resource extraction) and by the possibility of using oil money to finance rebellion, the opposition may resort to arms. Furthermore, the lack of effective influence over the decision-making process or the presence of resource-related grievances may provide an extra motive for violent uprising.

Much room remains for future research. By focusing on the number of political parties, this study was a first attempt at unifying the various strands of literature on the resource curse and the institutional determinants of intra-state violence. The results of the analysis show that the degree of competitiveness inherent to multi-party systems matters when assessing countries' internal conflict potential, pointing to the necessity for better differentiation between competitive and noncompetitive multi-party systems in future analyses. Also, subsequent work should study the interaction of resources with other institutional arrangements such as the degree of political centralization, government fractionalization and electoral or property rights systems. This will help to further prise open the institutional black box and contribute to our understanding of the political economy of resource-rich countries, as well as to generate more welcome and timely knowledge about the institutional foundations of violence within these countries. 


\section{Acknowledgements}

The author wishes to thank Matthias Basedau and five anonymous reviewers for their helpful comments. Georg Strüver provided excellent assistance with data.

\section{Funding}

Funding for writing this article was provided by the German Research Foundation (DFG), as part of the research projects 'Governing the Resource-Conflict Nexus' and 'Is Resource Wealth a Risk Factor?'

\section{Notes}

1. 'Multi-partyism', in which only one party holds effective political power, refers to situations in which there are multiple parties but no alteration in power, or when the major political party holds more than $75 \%$ of all congressional seats.

2. For an extensive overview of the possible mechanisms driving the relationship between natural resources and civil war, see Humphreys (2005) or Ross $(2004,2006)$.

3. Qualitative research has also stressed the role of government systems in promoting internal instability. Mainwaring (1993), for example, argues that multi-party presidentialism is especially likely to produce instability.

4. See also Vreeland (2008), who argues that the components of the widely used Polity Index (Gurr, 1989) include a factional category, making the relationship between 'anocracies' and internal violence a tautology.

5. The data on oil production comes from Humphreys (2005) and measures the average amounts of oil extracted per day in a given year (in millions of barrels per capita). It is important to note that this article concentrates on resource abundance rather than resource dependence (e.g. as measured by the total export of fuels per GDP). Basedau and Lay (2009) point to the necessity of making a clear distinction between resource wealth per capita and resource dependence when assessing conflict likelihood. Following the article's argument, it can be assumed that the availability of high per capita revenues from oil (rather than the importance of fuels within the country's export structure) provides a particular motive and means for rebellion.

6. The authors ignore multiple parties existing outside the legislature because 'the parties are not an instrument of the dictator' (Gandhi and Przeworski, 2006: 16). These cases are rare. The data was kindly provided by the authors.

7. When the 75 th percentile is used to define resource richness, $32 \%$ of oil-abundant states exhibit multiple parties.

8. The question of why autocratic, oil-abundant countries exhibit multiple parties is certainly interesting and deserves further attention. One obvious reason is that multi-party regimes were already in place prior to oil exploration (e.g. in Papua New Guinea, South Africa and Suriname). Another explanation is that autocratic petro-states may have to make institutional concessions in order to signal credible commitment and thwart the threat of rebellion, just like their oil-poor counterparts. Despite being oil-rich, states may lack sufficient oil revenues to ensure popular support or suppress dissent. This is especially the case in oil-abundant states in which particular political parties represent specific ethno-religious groups that have to be included in the political system. Examples of mineral-rich countries exhibiting so-called 'ethnic parties' (Horowitz, 1985) are the Democratic Republic of Congo, Myanmar, Nigeria and Trinidad and Tobago. Although a more thorough answer to this question lies beyond the scope of this article, it is likely that a modest oil per capita revenue and high ethno-religious diversity may prompt governments to establish political pluralism, thereby influencing the internal conflict potential.

9. A growing number of studies argue that as state violence increases and becomes arbitrary, it fosters rebel support and recruitment. Relying on household- and community-level data, Nillesen and Verwimp (2009) find that violent state repression furthered rebel recruitment in Uganda's civil war. Political violence employed by governments in order to limit the influence of opposition parties may increase the perceived sense of grievance among dissidents and sections of the population. 
10. Ross (2004) highlights the role of so-called 'booty futures' in order to finance rebellion in countries such as Liberia, Sierra Leone and the Republic of the Congo.

11. Non-competitive multi-party systems are considered to be systems in which only one party has effective political leverage. This means that multiple parties are legal but only one party holds legislative seats or one party retains more than $75 \%$ of total seats.

12. It is important to note that the alternation in power between the conservative and liberal party in Colombia was not a result of a competitive party system, but rather of a mutual agreement to divide power and avoid political competition (Mazzuca and Robinson, 2006).

13. A German contractor who participated in the construction of the Caño Limón-Conveñas pipeline is believed to have paid US\$4 million in extortion money to the National Liberation Army (ELN), the country's second-largest guerrilla group. The total oil-related extortion and ransom money in the late 1990s was around US\$140 million per year (Dunning and Wirpsa, 2004: 87).

14. The authors, however, also acknowledge that 'resource wealth is likely to tempt rebels only under circumstances of acute political uncertainty, as in the case of Congo's failed democratization effort' (Englebert and Ron, 2004: 62).

15. The few cases in between these categories (originally coded as 3.5, 5.5 and 6.5) were excluded from the analysis.

16. Table A2 in the Appendix displays the distribution of the different categories of liec across oil-rich and oil-poor countries. As can be noted, the general distribution patterns are similar across oil-abundant and oil-scarce states, dismissing possible problems arising from self-selection in the different categories.

17. During the period under analysis, a total of 155 civil violence outbreaks with 25 or more battle-related deaths were registered.

18. This is important given that observations of countries exhibiting a multi-party, non-competitive electoral system (liec5 and liec 6 ) are rather limited.

19. See Table A3 in the Appendix for further information on the definitions and sources for all the variables employed. Table A4 provides a summary of the variables' descriptive statistics.

20. Including an ethnic fractionalization index from Fearon and Laitin (2003), as well as an ethnic dominance measure from Collier and Hoeffler (2004), did not substantially alter the results.

21. Alternative lag structures were tested (all independent variables, including lparty, were lagged up to two years) and results did not change significantly. These estimations are available upon request.

22. This period of analysis reflects the limited availability of the employed DPI data set and the oil production data taken from Humphreys (2005).

23. In fact, an analysis of predictors' variance inflation factors pointed to the incidence of multicollinearity. Standard procedures such as centring the respective variables around their means could not attenuate the problem.

24. Note that countries with no legislature, an unelected legislature or one-candidate elections (liec1-liec3) serve as the reference category. Thus, all the results for liec4-liec 7 reflect the comparison with a situation of complete absence of political parties.

25. In Table 2, countries are considered oil-scarce when their per capita oil production does not exceed the sample's 75 th percentile.

26. Many oil-producing states fall into the oil-scarce subsample.

27. These results are available upon request.

28. In addition to the control variables reported earlier, measures of social diversity (fractionalization and polarization), political centralization, illiteracy, school enrolment, infant mortality, primary commodity exports, the percentage of the population under 15 years of age and military personnel were equally considered. To further minimize the risk of omitted-variable bias, the models were re-estimated without Middle Eastern and North African countries. Results did not change considerably.

29. A country was considered oil-dependent when more than one-third of its total exports consisted of oil. Data comes from Hegre and Sambanis (2006).

30. Although not reported here, calculations using the absolute oil production instead of the per capita figures are available upon request. 


\section{References}

Basedau M and Lay J (2009) Resource curse or rentier peace? The ambiguous effects of oil wealth and oil dependence on violent conflict. Journal of Peace Research 46(6): 757-776.

Basedau M and Wegenast T (2009) Oil and diamonds as causes of civil war in sub-Saharan Africa: Under what conditions? Colombia Internacional 70: 35-59.

Beck N, Katz JN and Tucker R (1998) Taking time seriously in binary time-series cross section analysis. American Journal of Political Science 42: 1260-1288.

Beck T, Clarke G, Groff A, et al. (2001) New tools in comparative political economy: The database of political institutions. World Bank Economic Review 15(1): 165-176.

Brunnschweiler CN and Bulte EH (2009) Natural resources and violent conflict: Resource abundance, dependence and the onset of civil war. Oxford Economic Papers 61(4): 651-674.

Carey SC (2007) Rebellion in Africa: Disaggregating the effect of political regimes. Journal of Peace Research 44(1): 47-64.

Collier P (2000) Doing well out of war: An economic perspective. In: Berdal M and Malone DM (eds) Greed \& Grievance: Economic Agendas in Civil Wars. London: Lynne Rienner, pp. 91-111.

Collier P and Hoeffler A (2004) Greed and grievance in civil war. Oxford Economic Papers 56(4): 563-595.

Collier P and Hoeffler A (2005) Resource rents, governance, and conflict. Journal of Conflict Resolution 49(4): 625-633.

Collier P and Hoeffler A (2006) The political economy of secession. In: Hannum H and Babbitt E (eds) Negotiating Self-Determination. Lanham, MD: Lexington Books, pp. 37-59.

De Soysa I (2000) The resource curse Are civil wars driven by rapacity or paucity. In: Berdal M and Malone DM (eds) Greed \& Grievance: Economic Agendas in Civil Wars. London: Lynne Rienner, pp. 113-135.

De Soysa I (2002) Paradise is a bazaar? Greed, creed and grievance in civil war 1989-1999. Journal of Peace Research 39(4): 395-416.

Dunning T and Wirpsa L (2004) Oil and the political economy of conflict in Colombia and beyond: A linkages approach. Geopolitics 9(1): 81-108.

Englebert P and Ron J (2004) Primary commodities and war: Congo-Brazzaville's ambivalent resource curse. Comparative Politics 37(1): 61-81.

Fearon JD (2005) Primary commodities exports and civil war. Journal of Conflict Resolution 49(4): 483-507.

Fearon JD and Laitin DD (2003) Ethnicity, insurgency, and civil war. American Political Science Review 97: 75-90.

Fjelde H (2009) Buying peace? Oil wealth, corruption and civil war 1985-1999. Journal of Peace Research 46(2): 199-218.

Gandhi J and Przeworski A (2006) Cooperation, cooptation, and rebellion under dictatorships. Economics \& Politics 18(1): 1-26.

Gandhi J and Przeworski A (2007) Authoritarian institutions and the survival of autocrats. Comparative Political Studies 40(11): 1279-1301.

Gleditsch NP, Wallensteen P, Eriksson M, et al. (2002) Armed conflict 1946-2001: A new dataset. Journal of Peace Research 39(5): 615-637.

Gurr TR (1989) Polity II: Political Structures and Regime Change, 1800-1986. Boulder, CO: Center for Comparative Politics.

Hegre H and Sambanis N (2006) Sensitivity analysis of empirical results on civil war onset. Journal of Conflict Resolution 50(4): 508-535.

Hegre H, Ellingsen T, Gates S, et al. (2001) Toward a democratic civil peace? Democracy, political change, and civil war, 1816-1992. American Political Science Review 95: 33-48.

Henderson EA and Singer JD (2000) Civil war in the post-colonial world, 1946-1992. Journal of Peace Research 37: 275-299.

Horowitz D (1985) Ethnic Groups in Conflict. Berkeley, CA: University of California Press.

Humphreys M (2005) Natural resources, conflict and conflict resolution: Uncovering the mechanisms. Journal of Conflict Resolution 49(4): 508-537.

Huntington S (1968) Political Order in Changing Societies. New Haven, CT: Yale University Press. 
Karl TL (1997) The Paradox of Plenty: Oil Booms and Petro-States. Berkeley, CA: University of California Press.

King G and Zeng L (2001) Logistic regression in rare events data. Political Analysis 9: 137-163.

Le Billon P (2001) The political ecology of war: Natural resources and armed conflicts. Political Geography 20: $561-584$.

Le Billon P (2008) Diamond wars? Conflict diamonds and geographies of resource wars. Annals of the Association of American Geographers 98(2): 345-372.

Lewis PM (1994) Economic statism, private capital, and the dilemmas of accumulation in Nigeria. World Development 22(3): 437-451.

Lijphart A (1977) Democracy in Plural Societies: A Comparative Exploration. New Haven, CT: Yale University Press.

Linz J (1973) Opposition to and under an authoritarian regime: The case of Spain. In: Dahl R (ed.) Regimes and Oppositions. New Haven, CT: Yale University Press.

Lujala P (2010) The spoils of nature: Armed civil conflict and rebel access to natural resource. Journal of Peace Research 47(1): 15-28.

Lujala P, Gleditsch NP and Gilmore E (2005) A diamond curse? Civil war and a lootable resource. Journal of Conflict Resolution 49(4): 538-562.

Mahdavy H (1970) Patterns and problems of economic development in rentier states: The case of Iran. In: Cook MA (ed.) Studies in the Economic History of the Middle-East. Oxford: Oxford University Press, pp. 428-468.

Mainwaring S (1993) Presidentialism, multipartism, and democracy. Comparative Political Studies 26(2): $198-228$.

Mazzuca S and Robinson J (2006) Political conflict and power-sharing in the origins of modern Colombia. NBER Working Paper No. 12099.

Nillesen E and Verwimp P (2009) Rebel recruitment in a coffee exporting economy. Microcon Research, Working Paper 11.

Obi CI (2001) Global, state and local intersections: Power, authority, and conflict in the Niger Delta oil communities. In: Challagy T, Kassimir R and Latham R (eds) Intervention and Transnationalism in Africa: Global-Local Networks of Power. Cambridge: Cambridge University Press, pp. 173-193.

O’Donnell G (1973) Modernization and Bureaucratic-Authoritarianism: Studies in South American Politics. Berkeley, CA: Institute of International Studies.

Pearce J (2004) Beyond the perimeter fence: Oil and armed conflict in Casanare. The Centre for Global Governance Discussion Paper 32, LSE.

Przeworski A, Alvarez M, Cheibub JA, et al. (2000) Democracy and Development. Cambridge: Cambridge University Press.

Ross ML (2003) The natural resource curse: How wealth can make you poor. In: Bannon I and Collier P (eds) Natural Resources and Violent Conflict: Options and Actions. Washington/DC: World Bank.

Ross ML (2004) How do natural resources influence civil war? Evidence from 13 cases. International Organization 58: 35-67.

Ross ML (2006) A closer look at oil, diamonds, and civil war. Annual Review of Political Science 9: 265-300.

Ross ML (2012) The Oil Curse: How Petroleum Wealth Shapes the Development of Nations. Princeton, NJ: Princeton University Press.

Saideman SM, Lanoue DJ, Campenni M, et al. (2002) 'Democratization, political institutions, and ethnic conflict - A pooled time-series analysis, 1985-1998. Comparative Political Studies 35(1): 103-129.

Schneider G and Wiesehomeier N (2008) Rules that matter: Political institutions and the diversity-conflict nexus. Journal of Peace Research 45(2): 183-203.

Shifter M (1999) Colombia on the brink. There goes the neighborhood. Foreign Affairs 78(4): 14-20.

Snyder R and Bhavnani R (2005) Diamonds, blood, and taxes: A revenue-centered framework for explaining political order. Journal of Conflict Resolution 49(4): 563-597.

Sorens J (2011) Mineral production, territory, and ethnic rebellion: The role of rebel constituencies. Journal of Peace Research 48(5): 571-585. 
Thies C (2010) Of rulers, rebels, and revenue: State capacity, civil war onset, and primary commodities. Journal of Peace Research 47(3): 321-332.

Vreeland JR (2008) The effect of political regime on civil war. Journal of Conflict Resolution 52(3): 401-425. Wimmer A (2003) Democracy and ethno-religious conflict in Iraq. Survival 45(4): 111-134.

Wright J (2008) Do authoritarian institutions constrain? How legislatures affect economic growth and investment. American Journal of Political Science 52(2): 322-343.

\section{Appendix}

Table AI. Dependent variable: internal conflict onset (violonset).

\begin{tabular}{|c|c|c|c|}
\hline & Model I (all countries) & $\begin{array}{l}\text { Model } 2 \text { (not oil-dependent, } \\
\text { less than I/3 of oil in total } \\
\text { exports) }\end{array}$ & $\begin{array}{l}\text { Model } 3 \text { (oil-dependent, } \\
\text { over I/3 of oil in total } \\
\text { exports) }\end{array}$ \\
\hline peace & $-0.012(0.009)$ & $-0.006(0.010)$ & $-0.0003(0.020)$ \\
\hline natwar $r_{(t-1)}$ & $0.184(0.208)$ & $0.073(0.245)$ & $-0.197(0.500)$ \\
\hline population $(\log )_{(\mathrm{t}-1)}$ & $0.330(0.058)^{\text {sekpok }}$ & 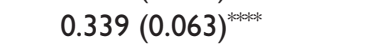 & $0.339(0.196)^{*}$ \\
\hline $\operatorname{gdppc}(\log )_{(\mathrm{t}-1)}$ & $-0.463(0.139)^{\text {*atk }}$ & $-0.682(0.175)^{* *+* * *}$ & $-0.403(0.339)$ \\
\hline partfree $_{(t-I)}$ & $-0.022(0.244)$ & $0.267(0.279)$ & $-0.494(0.579)$ \\
\hline regchange $_{(\mathrm{t}-\mathrm{l})}$ & $0.266(0.301)$ & $0.219(0.342)$ & $0.451(0.693)$ \\
\hline gdpgrowth $_{(t-1)}$ & $-2.015(1.902)$ & $-0.587(2.069)$ & $-5.264(3.210)$ \\
\hline dem_region $(t-1)$ & $0.012(0.023)$ & $0.014(0.026)$ & $0.093(0.066)$ \\
\hline terrain $_{(\mathrm{t}-\mathrm{l})}$ & $0.098(0.073)$ & $0.091(0.080)$ & $0.233(0.252)$ \\
\hline mena & $0.739(0.292)^{\text {** }}$ & $0.158(0.459)$ & $0.630(0.677)$ \\
\hline $\operatorname{liec} 4_{(t-1)}$ & $-0.016(0.373)$ & $-0.34 I(0.453)$ & $0.456(0.721)$ \\
\hline $\operatorname{liec5} 5_{(t-1)}^{(-1)}$ & $0.686(0.428)$ & $-0.736(1.032)$ & $1.379(0.747)^{*}$ \\
\hline $\operatorname{liec} 6_{(t-1)}^{(t-1)}$ & $0.811(0.306)^{* * * *}$ & $0.677(0.37 \mathrm{I})^{*}$ & $1.336(0.688)^{* *}$ \\
\hline $\operatorname{liec} 7_{(\mathrm{t}-1)}$ & $-0.062(0.262)$ & $0.053(0.293)$ & $-0.738(0.861)$ \\
\hline constant & 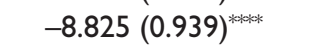 & $-9.019(1.007)^{* * * * *}$ & $-8.306(3.436)^{* * *}$ \\
\hline $\mathrm{N}$ & 3925 & 3358 & 567 \\
\hline Wald $\mathrm{chi}^{2}$ & 117.35 & 97.02 & 32.34 \\
\hline Prob $>$ chi $^{2}$ & 0.0000 & 0.0000 & 0.0036 \\
\hline $\begin{array}{l}\text { Pseudo } \mathrm{R}^{2} \\
\text { McKelvey \& } \\
\text { Zavoina's R² }\end{array}$ & $\begin{array}{l}0.0892 \\
0.198\end{array}$ & $\begin{array}{l}0.0903 \\
0.203\end{array}$ & $\begin{array}{l}0.1380 \\
0.321\end{array}$ \\
\hline
\end{tabular}

Notes: Logit estimation using robust standard errors (shown in parentheses).

$*_{\mathrm{p}}<10 \%$; ** $\mathrm{p}<5 \%$; *** $\mathrm{p}<1 \%$; **** $\mathrm{p}<0.1 \%$.

Table A2. Frequency of liec across oil-abundant and oil-scarce states.

\begin{tabular}{lccc}
\hline $\begin{array}{l}\text { Legislative index of electoral } \\
\text { competitiveness (liec) }\end{array}$ & Oil-abundant & Oil-scarce & Total \\
\hline NA & 7 & 57 & 64 \\
& $0.63 \%$ & $1.67 \%$ & $1.41 \%$ \\
& 135 & 358 & 493 \\
2 & $12.13 \%$ & $10.47 \%$ & $10.88 \%$ \\
& 86 & 132 & 218 \\
& $7.73 \%$ & $3.86 \%$ & $4.81 \%$ \\
\hline
\end{tabular}


Table A2. (Continued)

\begin{tabular}{lccc} 
Legislative index of electoral & Oil-abundant & Oil-scarce & Total \\
competitiveness (liec) & & & 262 \\
\hline 3 & 65 & 197 & $5.78 \%$ \\
& $5.84 \%$ & $5.76 \%$ & 127 \\
3.5 & 13 & 114 & $2.80 \%$ \\
4 & $1.17 \%$ & $3.34 \%$ & 425 \\
& 72 & 353 & $9.38 \%$ \\
5 & $6.47 \%$ & $10.33 \%$ & 152 \\
& 79 & 73 & $3.35 \%$ \\
5.5 & $7.10 \%$ & $2.14 \%$ & 10 \\
& 0 & 10 & $0.22 \%$ \\
6 & $0.00 \%$ & $0.29 \%$ & 468 \\
& 63 & 405 & $10.33 \%$ \\
6.5 & $5.66 \%$ & $11.85 \%$ & 38 \\
& 8 & 30 & $0.84 \%$ \\
7 & $0.72 \%$ & $0.88 \%$ & 2274 \\
& 585 & 1689 & $50.19 \%$ \\
Total & $52.56 \%$ & $49.41 \%$ & 4531 \\
& 113 & 3418 & $100 \%$ \\
\hline
\end{tabular}

Table A3. Variable definitions and data sources.

\begin{tabular}{|c|c|c|}
\hline Variable & Definition & Source \\
\hline violonset & $\begin{array}{l}\text { Intra-state conflict onset. 'I' if there is } \\
\text { the onset of conflict with more than } \\
25 \text { annual battle-related deaths; ' } 0 \text { ' } \\
\text { otherwise }\end{array}$ & $\begin{array}{l}\text { UCDPIPRIO Armed Conflict } \\
\text { Dataset, version 4/2007 } \\
\text { (Gleditsch et al., 2002) }\end{array}$ \\
\hline natwar & $\begin{array}{l}\text { Whether a neighbour is at war in a } \\
\text { given year }\end{array}$ & Hegre and Sambanis (2006) \\
\hline population (log) & Population, log-transformed & Hegre and Sambanis (2006) \\
\hline gdppc (log) & GDP per capita, log-transformed & Hegre and Sambanis (2006) \\
\hline partfree & $\begin{array}{l}\text { Inconsistency of political institutions. } \\
\text { States classified as 'partially free' } \\
\text { according to Freedom House }\end{array}$ & Hegre and Sambanis (2006) \\
\hline regchange & $\begin{array}{l}\text { Political instability as measured by the } \\
\text { number of years since an institutional } \\
\text { change that leads to a minimum of } \\
\text { three points' change on the Polity } \\
\text { index }\end{array}$ & Hegre and Sambanis (2006) \\
\hline gdpgrowth & Annual change in GDP, \% & Hegre and Sambanis (2006) \\
\hline dem_region & $\begin{array}{l}\text { Median regional democracy level } \\
\text { measured using Polity II }\end{array}$ & Hegre and Sambanis (2006) \\
\hline terrain & Rough terrain & Hegre and Sambanis (2006) \\
\hline mena & Region: Middle East and North Africa & Hegre and Sambanis (2006) \\
\hline
\end{tabular}


Table A3. (Continued)

\begin{tabular}{|c|c|c|}
\hline Variable & Definition & Source \\
\hline oil & $\begin{array}{l}\text { Daily per capita production of oil in } \\
\text { millions of barrels }\end{array}$ & Humphreys (2005) \\
\hline liec4 & $\begin{array}{l}\text { Dummy for political system with one } \\
\text { party and multiple candidates }\end{array}$ & $\begin{array}{l}\text { Database of Political Institutions } \\
\text { (DPI 2006) (Beck et al., 200I) }\end{array}$ \\
\hline liec5 & $\begin{array}{l}\text { Dummy for political systems where } \\
\text { multiple parties are legal, but only one } \\
\text { party won seats }\end{array}$ & $\begin{array}{l}\text { Database of Political Institutions } \\
\text { (DPI 2006) (Beck et al., 200I) }\end{array}$ \\
\hline liec6 & $\begin{array}{l}\text { Dummy for political systems where } \\
\text { multiple parties won seats, but the } \\
\text { largest party received more than } 75 \% \\
\text { of these }\end{array}$ & $\begin{array}{l}\text { Database of Political Institutions } \\
\text { (DPI 2006) (Beck et al., 200I) }\end{array}$ \\
\hline liec7 & $\begin{array}{l}\text { Dummy for political systems where } \\
\text { the largest party got less than } 75 \% \text { of } \\
\text { the seats }\end{array}$ & $\begin{array}{l}\text { Database of Political Institutions } \\
\text { (DPI 2006) (Beck et al., 200I) }\end{array}$ \\
\hline
\end{tabular}

Table A4. Descriptive statistics.

\begin{tabular}{|c|c|c|c|c|}
\hline Variable & Minimum & Maximum & Mean & Standard deviation \\
\hline violonset & 0 & I & 0.032 & 0.175 \\
\hline natwar & 0 & 60 & 0.379 & 0.485 \\
\hline population (log) & 10.434 & 20.947 & 15.446 & 1.765 \\
\hline gdppc (log) & -3.037 & 4.201 & 0.755 & 1.060 \\
\hline partfree & 0 & 1 & 0.227 & 0.419 \\
\hline regchange & 0 & I & 0.164 & 0.352 \\
\hline gdpgrowth & -0.521 & 1.55 & 0.020 & 0.067 \\
\hline dem_region & -8.5 & 10 & -1.902 & 6.070 \\
\hline terrain & 0 & 4.557 & 2.187 & 1.405 \\
\hline mena & 0 & I & 0.134 & 0.340 \\
\hline oil & 0 & 10.093 & 0.325 & 1.118 \\
\hline oil per capita & 0 & 4.923 & 0.045 & 0.270 \\
\hline liec4 & 0 & I & 0.043 & 0.204 \\
\hline liec5 & 0 & 1 & 0.014 & 0.116 \\
\hline liec6 & 0 & I & 0.050 & 0.217 \\
\hline liec7 & 0 & 1 & 0.234 & 0.426 \\
\hline
\end{tabular}

\section{Author biography}

Tim Wegenast is a research fellow at the Department of Politics and Management, University of Konstanz, and a research associate at the German Institute of Global and Area Studies in Hamburg, Germany. He holds a $\mathrm{PhD}$ in Political Science from the University Pompeu Fabra, Barcelona, Spain. His main research interests include the economic history of development, natural resources and intrastate conflict, social inequalities and Brazilian politics. He has published in journals such as Kyklos, Terrorism and Political Violence or Revista de Historia Económica. 